\title{
GANGGUAN HASRAT SEKSUAL PADA WANITA PASCASALIN DAN HUBUNGANNYA DENGAN CARA PERSALINAN
}

\author{
${ }^{1}$ Yusnia Irchami F, Irfan H, ${ }^{1}$ Isanawidya H.P, ${ }^{1}$ Avie A.B, ${ }^{2}$ Edi Patmini, ${ }^{3}$ Agung Nugroho, \\ ${ }^{2}$ Muhammad Nurhadi Rahman
}

\begin{abstract}
Background: Sexual dysfunction in postpartum woman is closely related to the period of pregnancy and childbirth. One of the diagnostic criteria for sexual dysfunction is a sexual desire. Sexual desire disorder can be influenced by psychological factors and marriage relationship. However, there has been no consensus stating with certainty the effect of the method of delivery against sexual desire disorder in postpartum woman.

Objective: To assess association between delivery method and sexual desire disorder among postpartum woman in RSUD Panembahan Senopati Bantul Yogyakarta.

Method: A cross sectional study was conducted involving 53 subjects in spontaneous vaginal group and 49 subjects in sectio caesarea group. The Female Sexual Function Index (FSFI) questionnaire was administered to measure sexual desire disorder in 2-6 months postpartum woman. Data was analyzed using chi-square analysis. Result \& Discussion: In spontaneous vaginal group, $62.3 \%$ of the subjects experienced sexual desire disorder while in sectio caesarea group showed $55.1 \%(p=0.463)$. Spontaneous vaginal delivery increases the risk of sexual desire disorder, but not significant statistically (Prevalence ratio 1.130 convidence interval (CI) 0.814 to 1.569 ).

Conclusion: There was no significant relationship between the method of delivery and the prevalence of sexual desire disorder among postpartum woman in RSUD Panembahan Senopati Bantul, Yogyakarta.
\end{abstract}

Keywords: Sexual desire disorders, spontaneous vaginal delivery, sectio caesarea delivery, postpartum woman

\section{ABSTRAK}

Latar Belakang: Disfungsi seksual yang terjadi pada wanita pascasalin erat kaitannya dengan masa kehamilan dan persalinan. Salah satu kriteria diagnostik disfungsi seksual adalah hasrat seksual. Gangguan hasrat seksual dapat dipengaruhi oleh faktor psikologis wanita dan hubungan pernikahan. Namun, belum terdapat konsensus yang menyatakan dengan pasti pengaruh metode persalinan terhadap gangguan hasrat seksual pada wanita pascasalin.

Tujuan: Mengetahui hubungan antara metode persalinan terhadap prevalensi gangguan hasrat seksual pada wanita pascasalin di RSUD Panembahan Senopati Bantul Yogyakarta.

Metode: Desain penelitian ini adalah studi potong lintang (cross sectional) dengan melibatkan 53 subjek pada kelompok persalinan vaginal dan 49 subjek pada kelompok sectio caesarea. Kuesioner Female Sexual Function Index (FSFI) digunakan untuk mengukur gangguan hasrat seksual pada subjek yang berada pada bulan ke 2-6 periode pascasalin. Data dianalisis dengan analis chi-square.

Hasil \& Pembahasan: Pada kelompok vaginal spontan, sebesar $62,3 \%$ subjek mengalami gangguan hasrat seksual sedangkan pada kelompok sectio caesarea didapatkan hasil sebesar $55,1 \%(p=0,463)$. Persalinan vaginal spontan meningkatkan risiko terjadinya gangguan hasrat seksual secara tidak bermakna (Rasio prevalensi 1,130 convidence interval (Cl) 0,814-1,569).

Kesimpulan: Tidak terdapat hubungan yang bermakna antara metode persalinan dengan prevalensi gangguan hasrat seksual pada wanita pascasalin di RSUD Panembahan Senopati Bantul Yogyakarta.

Kata kunci: Gangguan hasrat seksual, persalinan vaginal spontan, persalinan sectio caesarea, wanita pascasalin

\footnotetext{
${ }^{1}$ Mahasiswa S1 Pendidikan Dokter Fakultas Kedokteran UGM

${ }^{2}$ Bagian Obstetri dan Ginekologi, Fakultas Kedokteran UGM / RSUP Dr. Sardjito

${ }^{3}$ Bagian Kesehatan Ibu dan Anak, Ilmu Kesehatan Masyarakat, Fakultas Kedokteran UGM
} 


\section{PENDAHULUAN}

Disfungsi seksual pada wanita didefinisikan sebagai gangguan yang terjadi pada salah satu atau lebih dari keseluruhan siklus respons seksual normal yang berpengaruh terhadap aktivitas seksualnya. Disfungsi seksual yang tidak segera ditangani dapat menyebabkan permasalahan yang lebih serius yaitu gangguan interpersonal dengan pasangannya. ${ }^{1} \mathrm{Pada}$ wanita, disfungsi seksual biasanya berkaitan dengan periode kehamilan dan persalinan. ${ }^{2}$ Wang et al. (2003)dalam penelitiannya pada 460 subjek di Cina melaporkan bahwa sebanyak $70,59 \%$ wanita mengalami disfungsi seksual pada 3 bulan awal periode pascasalin. Jumlah ini mengalami penurunan setelah lebih dari 3 bulan periode pascasalin yaitu menjadi $55,63 \%$ pada bulan ke 3-6 dan menjadi $34,17 \%$ setelah melewati bulan ke $6 .^{3}$

Berdasarkan klasifikasi dalam Diagnostic and Statistical Manual of Mental Disorders, 4th Edition, Text Revision (DSM IV TR) oleh American Psyichiatric Association (APA), gangguan hasrat seksual merupakan salah satu kriteria diagnostik untuk disfungsi seksual. Penurunan hasrat seksual juga merupakan satu dari tiga permasalahan utama yang sering terjadi pada 3 bulan awal periode pascasalin dibandingkan pada saat kehamilan.'Penelitian yang dilakukan oleh Kettle et al. melaporkan bahwa beberapa subjek mengalami penurunan hasrat seksual pada awal periode pascasalin.t Barrett et al.juga menemukan bahwa terdapat penurunan hasrat seksual pada $53 \%$ dan $37 \%$ subjek di 3 bulan dan 6 bulan awal postpartum.u Penelitian yang dilakukan oleh Safarinejad et al. mengemukakan adanya perbedaan prevalensi gangguan hasrat seksual pada kelompok persalinan vaginal spontan $(46,7 \%)$ yang mencapai dua kali lipat dibandingkan dengan kelompok seksio cesarea $(20,2 \%)(1)$. Gangguan hasrat seksual dapat dipengaruhi oleh faktor psikologis ibu dan hubungan pernikahan, namun belum terdapat konsensus yang menyatakan dengan pasti pengaruh metode persalinan terhadap gangguan hasrat seksual postpartum.v

\section{METODE PENELITIAN}

Penelitian dilakukan pada bulan Juni hingga bulan Desember tahun 2014. Penelitian ini menggunakan data primer berupa kuesioner. Populasi penelitian ini adalah wanita pascasalin yang melakukan persalinan di RSUD Panembahan Senopati Bantul. Total subjek penelitian berjumlah 103 wanita pascasalin yang dipilih melalui teknik purposive sampling. Subjek penelitian diseleksi melalui kriteria inklusi dan kriteria eksklusi.

Kriteria inklusi meliputi wanita pascasalin berusia 17-50 tahun dalam rentang waktu 2-6 bulan periode pascasalin, pasien pascasalin dengan metode persalinan vaginal spontan dan sectio caesarea, dan bersedia dilibatkan dalam penelitian dengan menandatangani lembar informed consent. Kriteria eksklusi yaitu pasien yang dilakukan ekstraksi vakum dan tindakan episiotomi, memiliki penyakit genitalia, tidak menyusui, mengalami gangguan mental, mengonsumsi obat antidepressan, bayi gemelli, fetus/bayi mengalami kelainan kongenital atau meninggal, dan data kuesioner tidak lengkap.

Pengumpulan data dilakukan melalui pengisian kuesioner data pribadi, demografi, dan Female Sexual Function Index (FSFI) oleh subjek. Kuesioner FSFI yang telah diadaptasi dengan menggunakan Bahasa Indonesia terdiri dari 19 pertanyaan multidimensional seksual perempuan dan mencakup 6 domain dasar fungsi seksual perempuan, yaitu hasrat seksual (desire), rangsang seksual (arousal), lubrikasi, orgasme, kepuasan seksual, dan nyeri dalam berhubungan seksual. Alasan penggunaan kuesioner FSFI adalah kuesioner tersebut mencakup aspek gangguan hasrat seksual dan telah lulus uji validasi.

Kuesioner FSFI menyediakan 4-6 jawaban yang masing-masing memiliki bobot dan nilai. Apabila subjek memiliki skor $\mathrm{FSFI}<3,6$ pada domain hasrat seksual, maka subjek dapat diduga mengalami gangguan hasrat seksual.w Data akan berbentuk 2 kategori, yaitu mengalami gangguan hasrat seksual 
dan tidak mengalami gangguan hasrat seksual. Skala yang digunakan dalam menganalisis data adalah skala nominal. Kekuatan hubungan antara 2 variabel diuji dengan uji chi-square.

\section{HASIL DAN PEMBAHASAN}

Jumlah wanita yang tercatat melakukan persalinan di RSUD Panembahan Senopati Bantul antara bulan Maret 2014 hingga Agustus 2014 adalah sebanyak 1207 pasien. Pada periode penelitian, peneliti melakukan kunjungan rumah ke 194 subjek. Diperoleh 102 subjek yang memenuhi kriteria inklusi dan ekslusi, yaitu 53 subjek dari kelompok persalinan vaginal spontan dan 49 subjek dari kelompok sectio caesarea.Karakteristik data dasar subjek penelitian ditunjukkan pada tabel 1 , sementara untuk analisis Jenis persalinan terhadap gangguan hasrat seksual dapat dilihat pada tabel 2 .

Tabel 1. Karakteristik Umum Subjek Penelitian Berdasarkan Jenis Persalinan

\begin{tabular}{|c|c|c|c|}
\hline VARIABEL & $\begin{array}{l}\text { Vaginal Spontan } \\
\qquad(\mathrm{N}=53)\end{array}$ & $\begin{array}{l}\text { Sectio Caesarea } \\
\qquad(N=49)\end{array}$ & $p$ \\
\hline Usia (tahun, meantSD) & $31,36 \pm 4,744$ & $30,31 \pm 5,217$ & 0,289 \\
\hline Usia pernikahan (tahun, mean $\pm S D$ ) & $7,66 \pm 5,338$ & $6,16 \pm 4,602$ & 0,134 \\
\hline Usia Kehamilan (tahun, mean $\pm S D$ ) & $38,13 \pm 2,781$ & $39,12 \pm 2,412$ & 0,058 \\
\hline \multicolumn{4}{|l|}{ Paritas (jumlah, \%) } \\
\hline Primipara & $9(8,8)$ & $21(20,6)$ & $0,004^{*}$ \\
\hline Multipara & $44(43,1)$ & $28(27,5)$ & \\
\hline \multicolumn{4}{|l|}{ Tingkat Pendidikan(jumlah, \%) } \\
\hline SD & $6(5,9)$ & $3(2,9)$ & \\
\hline SMP & $15(14,7)$ & $12(11,8)$ & \\
\hline SMA & $27(26,5)$ & $29(28,4)$ & \\
\hline Perguruan Tinggi & $5(4,9)$ & $5(4,9)$ & \\
\hline \multicolumn{4}{|l|}{ Pekerjaan (jumlah,\%) } \\
\hline Ibu Rumah Tangga & $34(33,3)$ & $35(34,3)$ & \\
\hline PNS & $1(1,0)$ & $0(0,0)$ & \\
\hline Pegawai Swasta & $7(6,9)$ & $4(3,9)$ & \\
\hline Buruh & $3(2,9)$ & $2(2,0)$ & \\
\hline Pedagang & $1(1,0)$ & $1(1,0)$ & \\
\hline Lain-lain & $7(6,9)$ & $7(6,9)$ & \\
\hline \multicolumn{4}{|l|}{ Jenis Kelamin Bayi (jumlah, \%) } \\
\hline Laki-laki & $26(25,5)$ & $21(20,6)$ & 0,530 \\
\hline Perempuan & $27(26,5)$ & $28(27,5)$ & \\
\hline \multicolumn{4}{|l|}{$\begin{array}{l}\text { Bulan periode pascasalin } \\
\text { (jumlah,\%) }\end{array}$} \\
\hline 2 & $1(1,0)$ & $0(0,0)$ & \\
\hline 3 & $19(18,6)$ & $17(16,7)$ & \\
\hline 4 & $22(21,6)$ & $23(22,5)$ & \\
\hline 5 & $8(7,8)$ & $9(8,8)$ & \\
\hline 6 & $3(2,9)$ & $0(0,0)$ & \\
\hline
\end{tabular}


Tabel 2. Analisis Statistik Jenis Persalinan terhadap Gangguan Hasrat

\begin{tabular}{|c|c|c|c|c|c|c|c|c|}
\hline & & \multicolumn{4}{|c|}{ Gangguan Hasrat } & \multirow{3}{*}{ Total } & \multirow{3}{*}{ PR $(95 \% \mathrm{Cl})$} & \multirow{3}{*}{$p^{*}$} \\
\hline & & \multicolumn{2}{|c|}{ Disfungsi } & \multicolumn{2}{|c|}{ Tidak Disfungsi } & & & \\
\hline & & $\mathbf{n}$ & $\%$ & $\mathbf{n}$ & $\%$ & & & \\
\hline \multirow{3}{*}{$\begin{array}{c}\text { Jenis } \\
\text { Persalinan }\end{array}$} & Vaginal Spontan & 33 & 62,3 & 20 & 37,7 & 53 & 1,130 & \multirow{2}{*}{0,463} \\
\hline & Sectio Cesarea & 27 & 55,1 & 22 & 44,9 & 49 & $0,814-1,569$ & \\
\hline & Total & 60 & 58,8 & 42 & 41,2 & 102 & & \\
\hline
\end{tabular}

Sejumlah $26,5 \%$ subjek melakukan hubungan seksual pertama kali pada 8 minggu periode pascasalin, sedangkan $34,3 \%$ belum melakukan hubungan seksual. Berdasarkan hasil wawancara, alasannya antara lain rasa malas para ibu akibat terlalu lelah mengurus anak, rasa tidak percaya diri akan perubahan bentuk tubuh setelah melahirkan, dan tidak adanya hasrat untuk melakukan hubungan seksual.

Gangguan hasrat seksual pada penelitian ini ditemukan pada 59,2\% subjek. Berbagai penelitian lain menemukan nilai yang berbeda, antara lain sebesar 65,6\% (Ekaratni, 2006), 49,6\% (Elnashar et al., 2007), 22\% (Ponholzer et al., 2005), 34,1\% (Mohammadi et al., 2013), 56,7\% (Gun et al., 2013), dan 18,9\% (Grewal et al., 2014).x \{ ${ }^{13}$ Penelitian ini menunjukkan bahwa tidak ada hubungan yang bermakna antara metode persalinan dengan gangguan hasrat seksual. Hasil ini didukung oleh penelitian Dabiri et. al. (2014) yang menyatakan bahwa fungsi seksual tidak berhubungan dengan cara persalinan. Hosseini et al. (2012) juga menemukan tidak terdapat perbedaan hasrat seksual $(p=0,55)$ antara wanita yang menjalani persalinan vaginal spontan dan sectio caesarea pada 6-24 bulan periode pascasalin. ${ }^{1} \mathrm{t}$

Hasil yang berbeda ditunjukkan oleh penelitian Eid et al. pada tahun 2015 yang menunjukkan bahwa terdapat penurunan skor disfungsi seksual pada wanita yang melahirkan secara vaginal normal dibandingkan dengan sectio caesarea.

\section{KESIMPULAN DAN SARAN}

Tidak ditemukan adanya hubungan yang bermakna antara metode persalinan dengan prevalensi gangguan hasrat seksual pada wanita pascasalin di RSUD Panembahan Senopati Bantul Yogyakarta. Persalinan vaginal spontan meningkatkan risiko terjadinya gangguan hasrat seksual, namun tidak signifikan secara statistik.

\section{DAFTAR PUSTAKA}

1. American Psychiatric Association. DSM-IV-TR Diagnostic Criteria for Sexual Dysfunctions. 2000;(1):2000.

2. Wylie K. Assessment \& management of sexual problems in women. J R Soc Med. 2007;100:547-50.

3. T utolo M, Briganti a., Suardi N, Gallina a., Abdollah F, Capitanio U, et al. Optimizing postoperative sexual function after radical prostatectomy. Ther Adv Urol. 2012;4:347-65.

4. Kettle C, Ismail KM, O’Mahony F. Dyspareunia following childbirth. Obstet Gynaecol [Internet]. 2005;7:245-9. Available from:http://doi.wiley.com/ 10.1576/toag.7.4.245.27119

5. Barrett G, Pendry E, Peacock J, Victor C, Thakar R, Manyonda I. Women's sexual health after childbirth. BJOG. 2000;107(2):186-95.

6. Safarinejad MR, Kolahi AA, Hosseini L. The effect of the mode of delivery on the quality of life, sexual function, and sexual satisfaction in primiparous women and their husbands. J Sex Med. 2009;6:164567.

7. Gun K, Uludag M, Cidem M, Akman T, Ozbayrak S, Ornek NI, et al. Sexual dysfunction in premenopausal women with fibromyalgia. 2013;29:429-35. 
8. Ekaratni, M. J. A. Risiko Disfungsi Seksual pada Perempuan Pemakai Kontrasepsi Depo Medroxy Progesterone Acetate di Kabupaten Purworejo. Universitas Gadjah Mada. 2006.

9. Elnashar, A. M., Ibrahim, M. E. D., El-Desoky, M. M., Ali, O. M., \& Hassan, M. E. S. M. Female sexual dysfunction in Lower Egypt. BJOG: An International Journal of Obstetrics and Gynaecology (2007). 2003:201-206.

10. Ponholzer, A., Roehlich, M., Racz, U., Temml, C., \& Madersbacher, S. Female sexual dysfunction in a healthy austrian cohort: Prevalence and risk factors. European Urology. 2005; 47:366-374.

11. Mohammadi, K., Rahnama, P., Mohseni, S. M., Sahraian, M. A., \& Montazeri, A. Determinants of sexual dysfunction in women with multiple sclerosis. BMC Neurology. 2013;13:83.

12. Gun, K., Uludag, M., Cidem, M., Akman, T., Ozbayrak, S., Ornek, N. I., Akarirmak, U. Sexual dysfunction in premenopausal women with fibromyalgia. Acta Medica Mediterranea. 2013;29:429-435.

13. Grewal, G. S., Gill, J. S., Sidi, H., Gurpreet, K., Jambunathan, S. T., Suffee, N. J., Das, S. Prevalence and risk factors of female sexual dysfunction among healthcare personnel in malaysia. Comprehensive Psychiatry. 2014; 55: S17-S22.

14. Hosseini, L, Iran-Pour, E \& Safarinejad, MR. Sexual Function of Primiparous Women After Elective Cesarean Section and Normal Vaginal Delivery. Female Urology. 2012;9:498-504. 